\title{
Upregulation of GH, but not IGF1, in the hippocampus of the lactating dam after kainic acid injury
}

\author{
Elvira C Arellanes-Licea ${ }^{\dagger}$, José Ávila-Mendoza, Elizabeth C Ramírez-Martínez, Eugenia Ramos, \\ Nancy Uribe-González, Carlos Arámburo, Teresa Morales* and Maricela Luna*
}

Neurobiología Celular y Molecular, Instituto de Neurobiología, Campus Juriquilla, Universidad Nacional Autónoma de México, Querétaro, México

Correspondence should be addressed to M Luna or T Morales: lunam@unam.mx or marter@unam.mx

*(T Morales and $\mathrm{M}$ Luna contributed equally to this work)

${ }^{\dagger}$ (E C Arellanes-Licea is now at Academic Division, Universidad Tecnológica de Corregidora, Corregidora, Querétaro, México)

\begin{abstract}
Lactation embodies a natural model of morphological, neurochemical, and functional brain plasticity. In this reproductive stage, the hippocampus of the female is less sensitive to excitotoxins in contrast to nulliparity. Growth hormone (GH) and insulinlike growth factor 1 (IGF1) are known to be neuroprotective in several experimental models of brain lesion. Here, activation of the GH-IGF1 pituitary-brain axis following kainic acid ( $7.5 \mathrm{mg} / \mathrm{kg}$ i.p. KA) lesion was studied in lactating and nulliparous rats. Serum concentrations of GH and IGF1 were uncoupled in lactation. Compared to virgin rats, the basal concentration of GH increased up to $40 \%$ but IGF1 decreased $58 \%$ in dams, and only $\mathrm{GH}$ increased further after KA treatment. In the hippocampus, basal expression of GH mRNA was higher (2.8-fold) in lactating rats than in virgin rats. GH mRNA expression in lactating rats increased further after KA administration in the hippocampus and in the hypothalamus, in parallel to $\mathrm{GH}$ protein concentration in the hippocampus of KA-treated lactating rats ( $43 \%$ vs lactating control), as detected by Western blot and immunofluorescence. Except for the significantly lower mRNA concentration in the liver of lactating rats, IGF1 expression was not altered by the reproductive condition or by KA treatment in the hippocampus and hypothalamus. Present results indicate upregulation of GH expression in the hippocampus after an excitotoxic lesion, suggesting paracrine/ autocrine actions of $\mathrm{GH}$ as a factor underlying neuroprotection in the brain of the lactating dam. Since no induction of IGF1 was detected, present data suggest a direct action of $\mathrm{GH}$.
\end{abstract}

\author{
Key Words \\ - lactation \\ - growth hormone \\ - IGF1 \\ - hippocampus \\ - neuroprotection \\ - kainic acid
}

\section{Introduction}

In mammals, motherhood is accompanied by diverse adaptations as well as neural and behavioral plasticity, helping the female to cope with the demands of reproduction $(1,2,3)$. These adaptations confer neuroprotection to the hippocampus of the dam against excitotoxic damage caused by kainic acid (KA) administration during lactation $(4,5,6)$. KA acts as a neurotoxin inducing necrosis and apoptosis by generating reactive oxygen species and mitochondrial function disruption (7) in sensitive zones with high glutamate receptor concentration such as the hippocampus $(8,9)$.

Lactation is characterized by fluctuation of several hormones including growth hormone (GH) (10). GH is secreted mainly by the anterior pituitary gland, and it is http://www.endocrineconnections.org https://doi.org/10.1530/EC-17-0380
() 2018 The authors Published by Bioscientifica Ltd

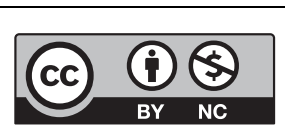

This work is licensed under a Creative Commons Attribution-NonCommercial 4.0 International License. 
known to regulate development and growth in vertebrates. During lactation, GH and other metabolic hormones increase to modulate the growth and metabolic features of the mammary gland (11), enhancing galactopoiesis in numerous mammalian species (12). GH is also synthesized in several, if not all, extra-pituitary tissues, including the nervous (13), immune (14) and reproductive systems (15). GH (protein or mRNA) is widely distributed in many brain regions, particularly in the hypothalamus (16) and hippocampus (17), both in neurons and in glial cells (18), indicating autocrine/paracrine actions involved in the regulation of neural growth, development and differentiation as well as in neurotransmission, behavior, neuroprotection and neuroplasticity $(19,20,21)$.

Neuroprotective actions of GH have been studied in response to trauma, stroke and hypoxic-ischemic brain injury. GH enhances tissue repair and the recovery of some neuronal functions $(22,23)$. These actions can take place by binding of $\mathrm{GH}$ to its specific receptor (GHR), which is present in different regions of the CNS $(24,25)$. GH binding can have a direct effect on the target cell (26) or can be mediated by the induction of IGF1 synthesis $(27,28)$, which has been implied as neuroprotective.

To date, it remains unknown whether GH and IGF1 expression in the hippocampus and hypothalamus is modified by lactation, and whether these hormones could have a role as neurotrophic factors in neuroprotection after acute damage induced by KA lesion. Thus, in this study, we determined the expression of the GH-IGF1 system (mRNA and protein) in brain regions vulnerable to excitotoxic injury as well as their serum concentration.

\section{Materials and methods}

\section{Animals}

Adult virgin (200-250g) or pregnant (250g; 18 days) female Wistar rats were housed individually under a 12:12-h light/darkness cycle, with controlled temperature and lighting conditions, and food and water available ad libitum. One day after parturition, litter sizes were culled to ten. Mothers were used for experiments on postpartum (pp) days 14-19. Vaginal smears of virgin rats were followed for at least four estrous cycles. The Institutional Animal Care and Use Committee of the Institute of Neurobiology at UNAM approved all experimental protocols. Animals were handled in accordance with the National Institutes of Health Guide for the Care and Use of Laboratory Animals.

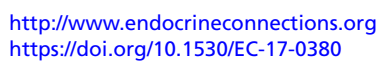

\section{Experimental design}

One group of nulliparous or lactating rats $(n=11$ per group) received $7.5 \mathrm{mg} / \mathrm{kg}$ of $\mathrm{KA}$ (Sigma-Aldrich) i.p. (nulliparous-KA and lactating-KA) or vehicle (nulliparousvehicle, lactating-vehicle) and were killed $24 \mathrm{~h}$ later by an i.p. overdose of $20 \%$ urethane $(2-3 \mathrm{~mL})(4,29)$. The pituitary gland, hypothalamus, hippocampus and liver were quickly dissected, frozen on dry ice and kept at $-70^{\circ} \mathrm{C}$ until further processing. Whole blood was taken for serum measurements. Other groups of rats with similar experimental treatments were processed and perfused (see below) for histological analysis. We characterized hypothalamic damage by TUNEL and Fluoro-Jade C staining, and we observed high apoptosis and neurodegeneration in the arcuate nucleus of nulliparous rats compared to lactating rats (unpublished data).

\section{Determination of GH and IGF1 concentration by ELISA}

Trunk blood was immediately collected in tubes for serum isolation (BD Vacutainer, BD Diagnostics, NJ, USA). Blood was centrifuged $\left(3000 \mathrm{~g}\right.$ at $4^{\circ} \mathrm{C}$ for $\left.15 \mathrm{~min}\right)$ to obtain serum. Aliquots were stored at $-70^{\circ} \mathrm{C}$. Serum GH was measured by competitive enzyme-linked immunosorbent assay (ELISA), as previously described (30). Briefly, $12 \mathrm{ng}$ of rat recombinant $\mathrm{GH}$ (National Hormone and Peptide Program, NIDDKD, San Diego, CA, USA) were used to coat microtiter plates overnight at $4^{\circ} \mathrm{C}$. After washing, we added the standards or samples $(20 \mu \mathrm{L}$ of serum). The primary antibody, a rabbit polyclonal anti-rat GH (Millipore), was used at a final dilution of 1:60,000. Later, the secondary antibody, a horseradish peroxidaseanti-rabbit immunoglobulin $G$ conjugate (Invitrogen) was used at a dilution of 1:3000 in $1 \%(\mathrm{w} / \mathrm{v})$ nonfat dry milk in TPBS $(0.01 \mathrm{M}$ sodium phosphate, $0.15 \mathrm{mM} \mathrm{NaCl}$, $0.05 \% \mathrm{w} / \mathrm{v}$ Tween $20, \mathrm{pH} 7)$. Bound secondary antibodies were then detected by reaction with HRP substrate (2,20-amino-di-[3-ethyl-benzothiazoline sulfate] (ABTS); Roche Diagnostics). All determinations were performed in triplicate. The inter- and intra-assay coefficients of variation were $<4 \%$.

$\mathrm{GH}$ immunoreactivity in tissue extracts from the pituitary, hypothalamus and hippocampus was detected as reported elsewhere (30) with minor modifications. Volumes of $400 \mu \mathrm{L}$ for the hippocampus and $200 \mu \mathrm{L}$ for the pituitary and hypothalamus of $0.1 \mathrm{M}$ Tris-buffered saline ( $\mathrm{pH}$ 10.3) containing Complete Protease Inhibitor Cocktail (Roche Diagnostics) and Teflon pistil were used

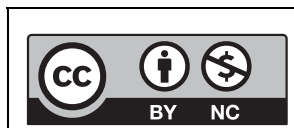

This work is licensed under a Creative Commons Attribution-NonCommercial 4.0 International License. 
to homogenate the tissue during 1 min on ice. Later, total proteins $(0.3 \mu \mathrm{g}$ for pituitary, $30 \mu \mathrm{g}$ for hippocampus, and $50 \mu \mathrm{g}$ for hypothalamus) were subjected to competitive ELISA as described earlier.

Serum-free IGF1 was quantified using a sandwich ELISA kit (ALPCO Immunoassays, Salem, NH, USA) according to the manufacturer's instructions. Determinations were performed in duplicate, using $50 \mu \mathrm{L}$ of serum (diluted 1:400 in sample buffer) per well, with inter- and intraassay coefficients of variation $<5 \%$. For measurement of IGF1 content in the tissue, we followed the previously reported method (30) with minor modifications. In short, $400 \mu \mathrm{L}$ of cold $1 \mathrm{X}$ RIPA buffer (Cell Signaling Technology) supplemented with Complete were added to liver fragments $\left(\sim 5 \mathrm{~mm}^{3}\right)$ and the suspension was homogenized 5 times and centrifuged at $12,000 \boldsymbol{g}$ for $20 \mathrm{~min}$ at $4^{\circ} \mathrm{C}$. The supernatant was transferred to a new tube to remove significant lipid fraction, and it was subjected to a second centrifugation for $10 \mathrm{~min}$. For whole hippocampus and hypothalamus, $150 \mu \mathrm{L}$ of cold RIPA buffer supplemented with Complete Protease Inhibitor Cocktail were added and homogenized as described earlier, with one centrifugation at $12,000 \mathrm{~g}$ for $20 \mathrm{~min}$ at $4^{\circ} \mathrm{C}$. The supernatant was aliquoted and stored at $-70^{\circ} \mathrm{C}$. Protein content of the three tissues was quantified by a microassay procedure based on the Bradford method following the supplier's instructions (Bio-Rad). Total soluble protein amounts $(15 \mu \mathrm{g}$ for the hypothalamus, $25 \mu \mathrm{g}$ for the hippocampus, and $5 \mu \mathrm{g}$ for the liver) were subjected to ELISA as described earlier, and results were plotted as ng of IGF1 per $\mu \mathrm{g}$ of tissue protein.

\section{GH and IGF1 gene expression: RNA extraction and cDNA synthesis}

Total RNA was extracted from whole hypothalamus, hippocampus, pituitary and liver pieces $\left(5 \mathrm{~mm}^{3}\right)$ per experimental individual using PureLink RNA mini kit (Ambion, Life Technologies). Genomic DNA contamination was removed from the column with the PureLink DNase (Invitrogen, Life Technologies). First-strand cDNAs were synthesized from $2 \mu \mathrm{g}$ total RNA using $100 \mathrm{U}$ of Superscript II reverse transcriptase (Invitrogen, Life Technologies), $0.5 \mu \mathrm{g}$ oligo $\mathrm{d}(\mathrm{T}), 0.5 \mu \mathrm{g}$ random hexamers and $1 \mathrm{mM}$ dNTPs for $50 \mathrm{~min}$ at $42^{\circ} \mathrm{C}$ followed by $15 \mathrm{~min}$ at $70^{\circ} \mathrm{C}$.

\section{Quantification of GH and IGF1 mRNA gene expression}

The relative abundance of GH and IGF1 mRNA expression was normalized with the endogenous reference genes hypoxanthine phosphoribosyl-transferase (HPRT) (31) and ribosomal protein S18 (RPS18) (32). Specific oligonucleotides were designed using Primer 7 software (Cascade, CO, USA) (Table 1). All real-time PCR reactions were carried out in a Roche LigthCycler 2.0 instrument (Roche Diagnostics) and using LigthCycler FastStart DNA Master SYBR Green I (Roche) in a final volume of $10 \mu \mathrm{L}$ containing: $3 \mu \mathrm{L}$ of cDNA (dilution 1:3 for hypothalamus and hippocampus, 1:5 for pituitary gland and 1:10 for liver), $2.5 \mathrm{mM} \mathrm{MgCl}_{2}$ and $0.5 \mu \mathrm{M}$ of each primer. The reactions were performed under the following conditions: initial denaturation at $95^{\circ} \mathrm{C}$ for $10 \mathrm{~min}$ followed by 40 cycles of $95^{\circ} \mathrm{C}$ for $10 \mathrm{~s}, 65^{\circ} \mathrm{C}$ (for $\mathrm{GH}$ and IGF1) or $60^{\circ} \mathrm{C}$ (for HPRT and RPS18 oligonucleotides) for $10 \mathrm{~s}$ and $72^{\circ} \mathrm{C}$ for $15 \mathrm{~s}$. The dissociation curve was run after each real-time PCR experiment to ensure that there was only one amplification product. Finally, the amplified product was sequenced to verify its identity. The relative expression of GH and IGF1 mRNAs was calculated using the comparative threshold cycle (CT) method and employing the formula $2^{-\Delta \Delta C T}$ (33), where quantification is expressed relative to the geometric mean of HPRT and RPS18 (34).

\section{Histology}

Rats were deeply anesthetized with a urethane overdose and transcardially perfused with $4 \%$ paraformaldehyde (Sigma-Aldrich) in phosphate-buffered saline (PBS) $(\mathrm{pH}$ $9.5,10^{\circ} \mathrm{C}$ ). Brains were removed, postfixed overnight and cryoprotected in 30\% sucrose-PBS solution at $4^{\circ} \mathrm{C}$. Coronal sections $(30 \mu \mathrm{m}$ thick) were cut along the dorsal hippocampus on a freezing microtome (Leica 2000R), and five series were collected and stored in cryoprotectant solution (30\% ethylene glycol and 20\% glycerol in PBS) at $-20^{\circ} \mathrm{C}$. One series was analyzed using each of the staining methods.

Table 1 Oligonucleotide primer sequences used in this study.

\begin{tabular}{|c|c|c|}
\hline Primer name & $\begin{array}{l}\text { Synthesis } \\
\text { direction }\end{array}$ & Sequence $\left(5^{\prime}-3^{\prime}\right)$ \\
\hline rGHqf & Forward & GGCCCAGCAGAGAACTGACAT \\
\hline rGHqr & Reverse & ATCAGAGCCTGGATGCCCTC \\
\hline rIGF1qf & Forward & ACCTTGCAAAAGTGGTCCTG \\
\hline rIGF1qr & Reverse & AGGAATTTAGTGCAACCGAA \\
\hline rHPRTqf & Forward & GACCGGTTCTGTCATGTCG \\
\hline rHPRTqr & Reverse & ACCTGGTTCATCATCACTAATCAC \\
\hline rRPS18qf & Forward & TTCAGCACATCCTGCGAGTA \\
\hline rRPS18qr & Reverse & TTGGTGAGGTCAATGTCTGC \\
\hline
\end{tabular}

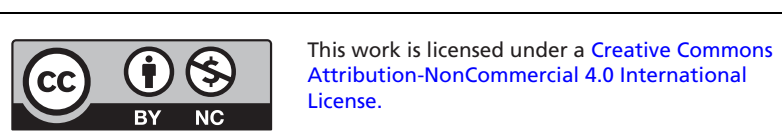



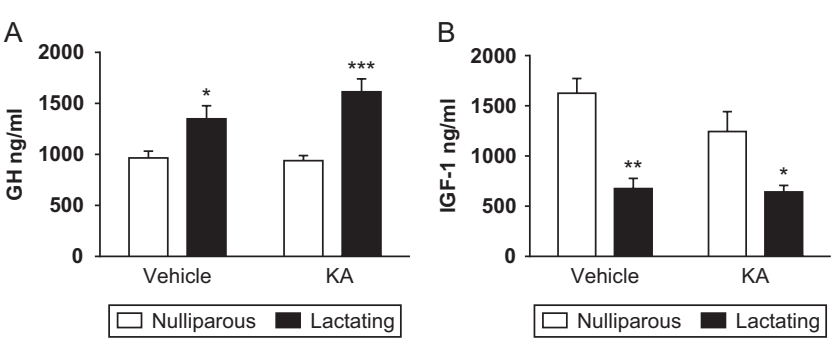

Figure 1

Serum concentration of GH/IGF1 in virgin and lactating rats after kainic acid (KA) or vehicle administration. White bars represent virgin rats and black bars represent lactating rats. Data are plotted as mean \pm S.E.M. (A) Seric concentration of $\mathrm{GH}$; symbols denote $* P<0.05$ and $* * * P<0.001$ vs nulliparous rats from each treatment, by unpaired Student's $t$-test $n=7-8$. (B) Seric concentration of IGF1; symbols denote $* P<0.05$ and $* * P<0.01$ vs nulliparous rats from each treatment, by unpaired Student's $t$-test, $n=4$.

\section{Relative GH gene expression in pituitary gland, hippocampus and hypothalamus}

Assessment of GH relative gene expression showed a significant decrease of GH mRNA in the pituitary gland (3.12-fold, $P<0.001)$ and hypothalamus (11.1-fold, $P<0.001$ ) of lactating rats (Fig. $2 \mathrm{~A}$ and $\mathrm{C}$ ) compared to virgin rats. The two-way ANOVA for pituitary GH mRNA expression showed significant differences depending on the reproductive status $(F(1,32)=56.06 ; \quad P<0.0001)$ and on the interaction between reproductive status and treatment $(F(1,32)=5.84 ; P<0.05)$. In contrast, lactation triggered a 2.8 -fold $(P<0.05)$ increase in $\mathrm{GH}$ mRNA levels in the hippocampus (Fig. 2B).

KA treatment differentially affected GH expression in the analyzed tissues. KA in the pituitary gland of nulliparous rats significantly decreased GH mRNA (1.34-fold) vs nulliparous vehicle $(P<0.05)$. This response to the excitotoxin was absent in lactating rats. GH mRNA levels in the hippocampus of lactating rats increased 7.6 -fold $(P<0.001)$ after KA vs nulliparous-KA rats and increased 2 -fold $(P<0.05)$ vs lactating control (Fig. 2B). The two-way ANOVA showed significant differences based on reproductive status $(F(1,32)=28.66 ; \quad P<0.0001)$ and on the interaction between reproductive status and treatment $(F(1,32)=6.94 ; P<0.05)$. No lesion effects were detected in the hippocampus of nulliparous rats.

KA injection induced a significant 3.3 -fold $(P<0.01)$ decrease in GH mRNA relative gene expression in the hypothalamus of virgin rats (Fig. 2C) compared to virginvehicle group, while $\mathrm{KA}$ administration to lactating rats induced a 4.2 -fold $(P<0.01)$ increase in GH mRNA relative gene expression vs the lactating-vehicle group. The two-way ANOVA showed the significant effects of http://www.endocrineconnections.org https://doi.org/10.1530/EC-17-0380
(C) 2018 The authors Published by Bioscientifica Ltd
This work is licensed under a Creative Commons Attribution-NonCommercial 4.0 International License. 

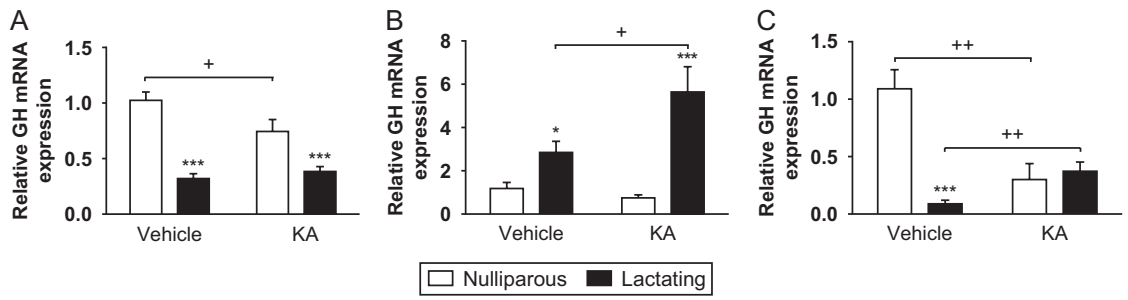

reproductive status, $(F(1,30)=14.81 ; P<0.001)$, treatment $(F(1,30)=4.40 ; P<0.05)$ and the interaction between both factors $(F(1,30)=19.82 ; P<0.0001)$.

In order to correlate $\mathrm{GH}$ protein content to $\mathrm{GH}$ mRNA in the analyzed tissues, concentration of GH, as determined by ELISA, was normalized to total protein in the pituitary gland, hippocampus and hypothalamus of virgin and lactating rats (Fig. 3). Pituitary and hypothalamic $\mathrm{GH}$ remained unchanged regardless of the treatments (Fig. 3A and C), but KA treatment significantly increased $\mathrm{GH}$ content in the hippocampus of lactating rats (43\%, $P<0.05)$ compared to lactating control (Fig. 3B). The two-way ANOVA showed an interaction between reproductive status and treatment factors $(F(1,12)=5.99$; $P<0.05)$.

\section{Relative gene expression of IGF1 mRNA and protein in liver, hippocampus and hypothalamus}

To determine whether IGF1 would increase in parallel with GH and thus mediate its effects, we quantified IGF1 mRNA levels in the main site of synthesis, the liver, as well as in the hippocampus and hypothalamus of rats in the different experimental groups. Hepatic levels of IGF1 were influenced by the reproductive status. The liver of lactating rats showed significantly reduced levels of IGF1, both in control (4.3-fold, $P<0.001$ ) and in KA-treated (4.8-fold, $P<0.001)$ groups compared to corresponding nulliparous groups (Fig. 4A). The two-way ANOVA showed significant differences based on reproductive status $(F(1,12)=380.63$; $P<0.0001)$ and treatment $(F(1,12)=6.62 ; \quad P<0.05)$. No differences were observed between relative gene expression of IGF1 in the hippocampus or hypothalamus based on the reproductive condition or KA treatment (Fig. 4B and C).

Quantification by ELISA showed no significant changes in IGF1 content normalized to hepatic protein in response to the reproductive condition or KA treatment (Fig. 5A). No changes in IGF1 concentration were detected in the hippocampus or in the hypothalamus; and as expected, IGF1 content was much lower than that in the liver (Fig. 5B and C).

\section{GH immunolocalization}

The immunohistochemical analysis revealed that GH immunoreactivity increased in the dentate gyrus of lactating rats treated with KA. Fig. 6 (upper panels) shows similar immunoreactivity and distribution that labeling for $\mathrm{GH}$ is in the granular cell layer (GCL) and hilus in dentate gyrus of nulliparous rats that received $\mathrm{KA}$ or vehicle, whereas KA strongly upregulated $\mathrm{GH}$ immunofluorescence in lactating dams (lower panels, Fig. 6), and similar results were observed in CA1 and CA3 (data no shown).
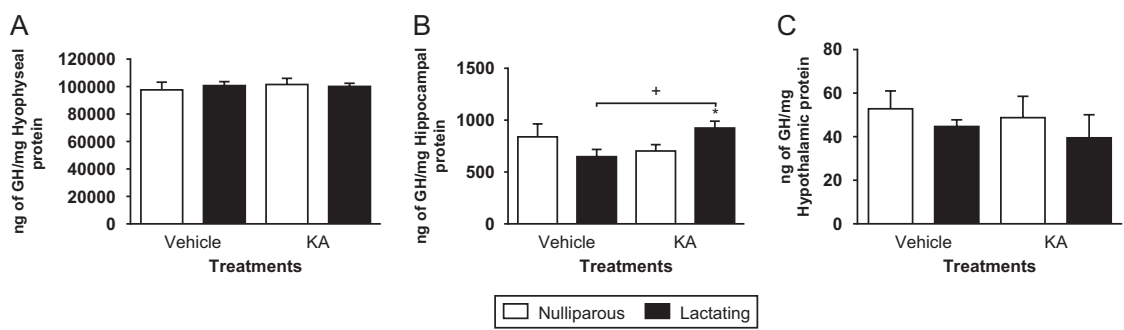

Figure 3

Protein content of $\mathrm{GH}$ in virgin and lactating rats after kainic acid (KA) treatment or vehicle administration. White bars represent nulliparous rats and black bars represent lactating rats. Data are plotted as mean \pm s.E.M. (A) Pituitary gland concentration of $\mathrm{GH}, n=4$, (B) hippocampal concentration of $\mathrm{GH}, n=4$ and (C) hypothalamic concentration of $\mathrm{GH}, n=3-4$. Symbols denote * $P<0.05$ vs nulliparous rats from each treatment; ${ }^{+} P<0.05$ inter-treatment differences by unpaired Student's $t$-test. http://www.endocrineconnections.org https://doi.org/10.1530/EC-17-0380
() 2018 The authors Published by Bioscientifica Ltd

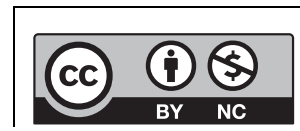

This work is licensed under a Creative Commons Attribution-NonCommercial 4.0 International License. 

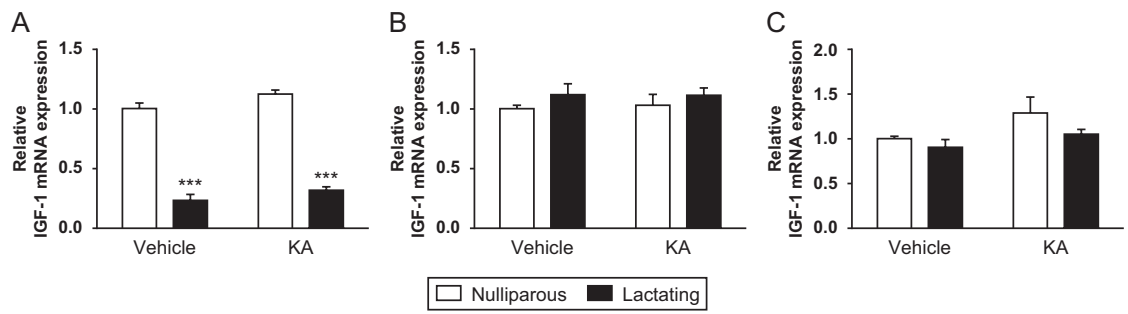

\begin{abstract}
Figure 4
Relative gene expression of IGF1 mRNA in female rats after kainic acid (KA) treatment or vehicle administration. White bars represent nulliparous rats and black bars represent lactating rats. Data are plotted as mean \pm S.E.M. Fold change in IGF1 mRNA relative gene expression in (A) liver $n=4$; (B) hippocampus, $n=5$ and (C) hypothalamus, $n=4-5$. Symbols denote $* * * P<0.001$ vs nulliparous rats from each treatment, by unpaired Student's $t$-test.
\end{abstract}

\section{Discussion}

The present research aimed to study responses of the GH/ IGF1 axis during lactation and after a brain lesion induced by excitotoxins, which would suggest involvement in neuroprotective actions $(2,5,35,36)$. Findings showed that GH/IGF1 circulating levels were uncoupled. Serum GH increased, while IGF1 concentration decreased in lactating rats. Suckling stimulation provided by the litter produces a rapid and transient increase of plasmatic GH in lactating rats on 9-10pp (37). This increase was observed throughout lactation, since we employed dams on 14-19 pp. Another study has shown increased plasma GH in rats during pregnancy but returned to basal levels in early lactation (day $8 \mathrm{pp}$ ). Moreover, plasma IGF1 decreased in pregnancy and remained unchanged in early lactation (38). These results are in contrast with ours, perhaps due to the stage of lactation: early vs late lactation (days 14-19), but the present study include diestrus virgin rats to compare GH or IGF1 levels to those of lactating rats (against non-lactating postpartum day 8 rats used by Escalada and coworkers (38). However, another study (39) showed that serum IGF1 concentrations and hepatic mRNA both decreased in mid-pregnancy and early lactation in mice, in contrast to GH levels in both reproductive stages; this reinforces our results regarding solely to divergence observed between increased serum GH during late lactation and decreased serum IGF-1 in this period. The contribution of peripheral GH to brain tissue levels is important because transport of this hormone through the blood-brain barrier (BBB) has been shown $(19,40)$. Moreover, KA excitotoxic damage increases the permeability of BBB in the hippocampus (41), which would allow circulating GH into the brain.

The GH/IGF1 ratio observed during middle and late lactation has been suggested as a GH-resisting state by Escalada and coworkers (38), who also found reduction in liver GHR mRNA in pregnant and early lactating rats. In agreement with our results, serum IGF1 on lactation days 12-14 has been reported as low as those of virgin rats (42). This GH-resisting state could explain the high GH/low IGF1 ratio found in the present study, and we hypothesize this could be due to the increased metabolic demands in lactating rats. Differences in the GH/IGF1 ratio due to changes in the metabolism have been demonstrated in fasting models where serum GH increased while levels of IGF1 are diminished (43).

Nevertheless, present results showed low relative GH gene expression and no effect of acute excitotoxic treatment in the pituitary gland of lactating rats (Fig. 2A). The lack of relationship between plasma and pituitary GH could result from a negative feedback of high levels of circulating GH upon its own transcription via negative short-loop regulation through hypothalamic somatostatin (SST, 44). In nulliparous rats, GH mRNA decreased after KA treatment, suggesting more sensitivity of the pituitary gland to excitotoxic damage (29). In contrast, GH content in the pituitary was not altered by lactation or KA administration. Escalada and coworkers (38) showed that pituitary GH content in early lactation was lower than in non-suckling rats, and they used a semiquantitative method to show that GH mRNA did not undergo significant modifications. In the present study, a quantitative method was utilized to determine GH mRNA
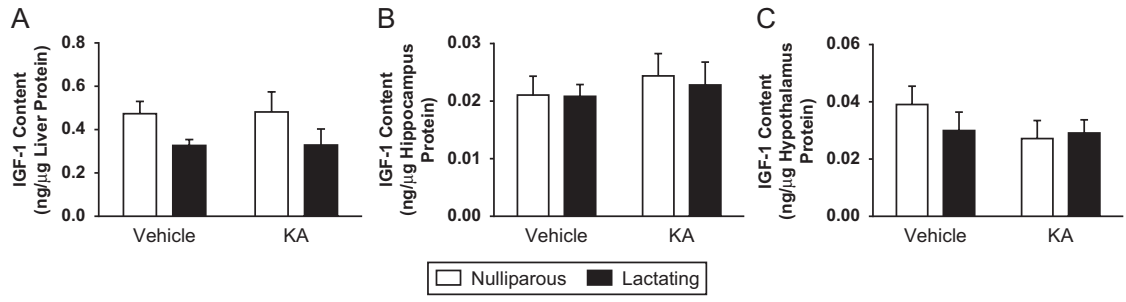

http://www.endocrineconnections.org https://doi.org/10.1530/EC-17-0380

(c) 2018 The authors Published by Bioscientifica Ltd

\section{Figure 5}

Protein content of IGF1 in female rats after kainic acid (KA) treatment or vehicle administration. White bars represent nulliparous rats and black bars represent lactating rats. Data are plotted as mean \pm S.E.M. (A) Hepatic concentration of IGF1, $n=4$. (B) Hippocampal concentration of IGF1, $n=3-4$. (C) Hypothalamic concentration of IGF1, $n=4$. 

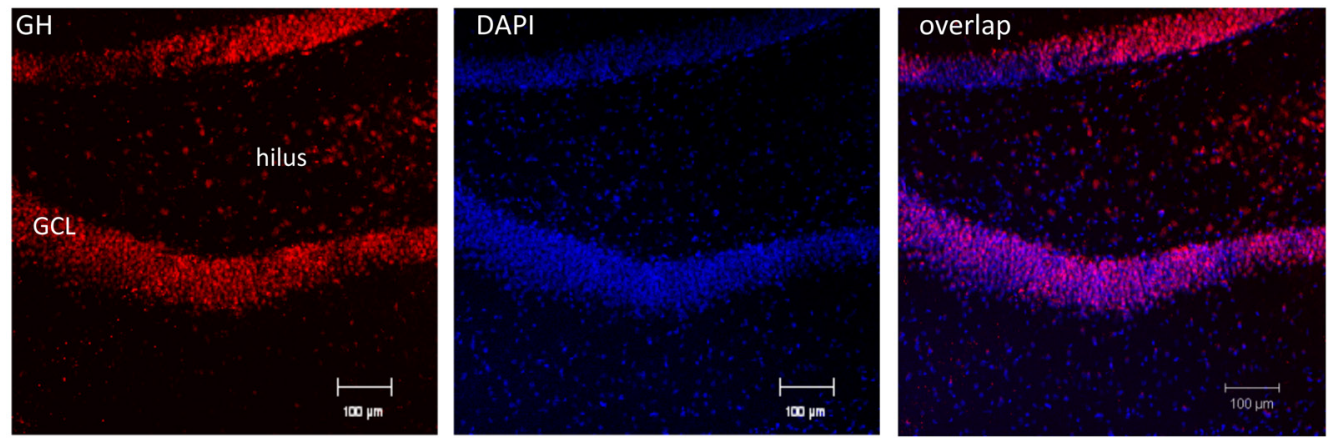

N-Veh
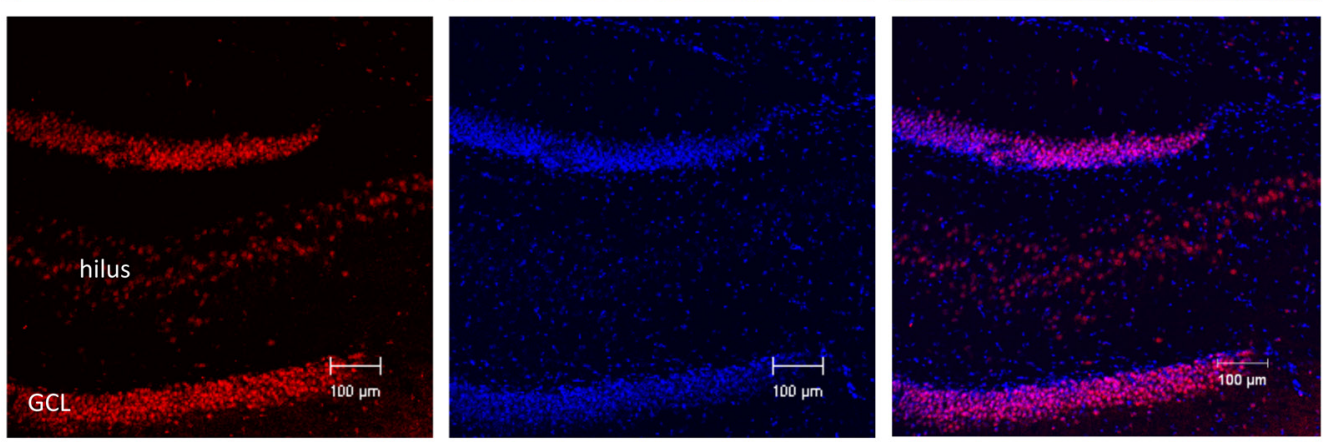

N-KA
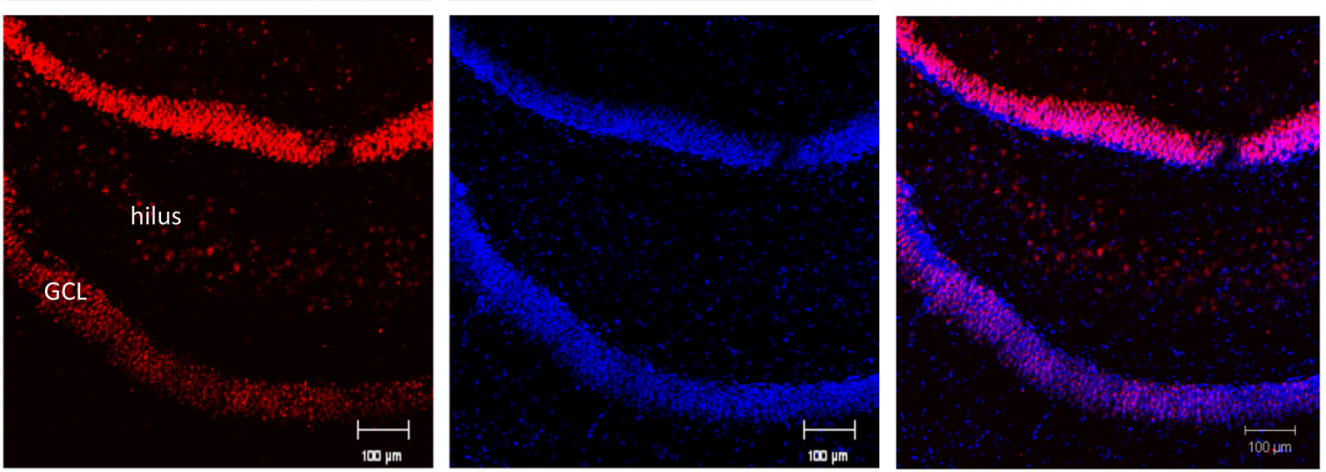

Lac-Veh

GCL
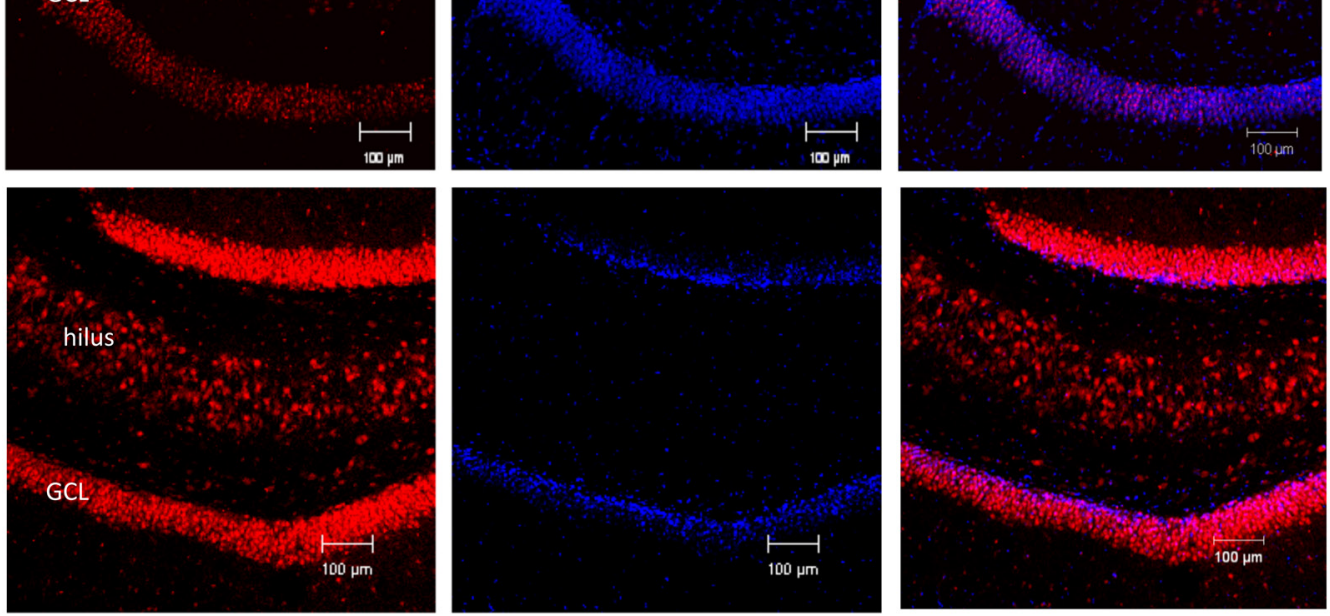

Lac-KA

Figure 6

GH immunoreactivity (GH-IR) located in the dentate gyrus of the hippocampus of female rats after kainic acid (KA) or vehicle (Veh) administration. Representative confocal microphotographs stained for GH and secondary antibody goat anti-rabbit IgG Cy3 (red), counterstained with DAPI (blue) and merged for the different experimental groups ( $N$, nulliparous; Lac, lactating rats). Increased GH-IR was detected in the hippocampus of lactating KA rats. Scale bar $=100 \mu \mathrm{m}$.

levels. GH expression in lactating rats was lower than that in virgin rats.

Interestingly, significant changes in GH expression were observed in the hippocampus. GH mRNA in the whole hippocampus of lactating rats was higher than that of nulliparous rats. Relative GH mRNA amount particularly increased after acute KA treatment in the hippocampus of lactating rats. In addition, we found that

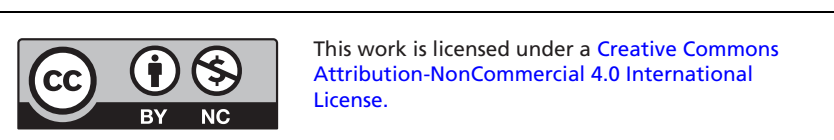


GH immunoreactivity augmented in the dentate gyrus of lactating rats treated with KA (Fig. 6), reflecting a high relative GH mRNA expression in the hippocampus. In previous studies, we found that the main areas of the dorsal hippocampus affected by KA in nulliparous rats were the CA1 and the hilus of the dentate gyrus, with high levels of apoptosis and neurodegeneration, in contrast to hippocampus of the lactating dams $(2,4,19)$. Thus, these data suggest that GH may play an autocrine/paracrine role as a survival factor $(19,45)$, possibly interacting with the positive regulation of hippocampal GH expression by estradiol (46). Concerning GHR, its expression in the hippocampus of male rats (18) has been reported, as well as changes in GHR expression in peripheral tissues during pregnancy and lactation $(38,47)$. However, further analysis of GHR through lactation in murine hippocampus is needed.

The potential role or synergism of $\mathrm{GH}$ with other mitogens in the recovery of neuronal injury is not fully elucidated (48). Studies in male rats have shown that acute KA and exogenous GH stimulate the proliferation of hippocampal precursors and upregulate local GH mRNA and protein expression (48). Our results provide evidence of the possible role of local hippocampal GH expression as one of the factors underlying neuroprotection in lactation, but further research on the molecular mechanisms that regulate $\mathrm{GH}$ gene transcription in this tissue is required.

Regarding GH mRNA in the hypothalamus, both basal and KA-induced levels of expression were different depending on the reproductive status. Basal level was high in nulliparous rats and low in lactating rats. Meanwhile, KA lesions provoked a reduction in nulliparous rats and a 4.2-fold increase in lactating rats. In parallel, we quantified GH protein content in the hypothalamus and did not find changes. This can be explained in part by the low expression level of GH protein per total protein tissue, which was $<1 \%$ of that found in the pituitary gland.

A primary GH action is the promotion of IGF1 synthesis and release, which mediates some effects of GH (49). Circulating concentration and hepatic expression of IGF1 mRNA were decreased in lactatingvehicle and lactating-KA groups compared to virgin rats. Moreover, the acute KA injection had no effect on reproductive condition. Unlike $\mathrm{GH}$ in the hippocampus of lactating rats, we observed no changes in hippocampal IGF1 synthesis in the experimental groups. This result indicates that potential GH action during hippocampal neuroprotection would be direct and non-mediated by IGF1 (50). Similarly, neuroprotective effects of GH in the hypoxic-ischemic brain injury model are not mediated

$$
\text { http://www.endocrineconnections.org }
$$

by IGF1 (26). Nevertheless, chronic treatment with GH caused an augmented synthesis of IGF1 mRNA in the hypothalamus and hippocampus of male rats, along with cell survival and neuroprotective pathway activation (51). Moreover, intrahippocampal administration of IGF1 with KA showed neuroprotective effects (52). It has been shown that $\mathrm{GH}$ has protective effects on the cerebellum of chicken embryos subjected to hypoxia-ischemia conditions by increasing the concentration of survival factors such as Bcl-2 and p-Akt (53). Furthermore, administration of GH, or its local overexpression, promotes cell survival and IGF1 expression in quail retinal ganglion cell lines (QNR/D) exposed to excitotoxic conditions (54). Also, both endogenous GH and IGF1 expression were significantly increased in the iguana neuroretina in response to KA injury, and it was shown that GH was able to exert, either directly or mediated by IGF1, a neuroprotective action against excitotoxic damage (55).

\section{Conclusion}

Present studies demonstrate that the GH/IGF1 axis responds to lactation and acute KA lesions. The later upregulates $\mathrm{GH}$ mRNA and protein expression in the hippocampus, particularly in the dentate gyrus, without modifying IGF1 expression. This suggests that local GH might play a role in hippocampal neuroprotection against excitotoxic damage. Further analysis is needed to quantify the presence and anatomical distribution of GHR in the hippocampus of the lactating rat, and the intracellular pathways that mediate its actions. Consideration should be given to the crosstalk with prolactin signaling, since $\mathrm{GH}$ seems to signal via the prolactin receptor to promote the migration of neurogenic radial glia from fetal human forebrains (56).

\section{Declaration of interest}

The authors declare that there is no conflict of interest that could be perceived as prejudicing the impartiality of the research reported.

\section{Funding}

This work was supported by UNAM-DGAPA-PAPIT: IN202315, IN204718; IN206115, and IN201817.

\section{Acknowledgements}

The authors thank Martha Carranza, Dr Anaid Antaramian, Adriana González-Gallardo and Nydia Hernández for their technical support; Dr Mauricio Díaz-Muñoz for his laboratory facilities; Dr Martín García and Dr Alejandra Castilla for animal care and Jessica González Norris for editing the manuscript. 


\section{References}

1 Kinsley CH, Bardi M, Karelina K, Rima B, Christon L, Friedenberg J \& Griffin G. Motherhood induces and maintains behavioral and neural plasticity across the lifespan in the rat. Archives of Sexual Behavior 200837 43-56. (https://doi.org/10.1007/s10508-007-9277-x)

2 Morales T. Recent findings on neuroprotection against excitotoxicity in the hippocampus of female rats. Journal of Neuroendocrinology 2011 23 994-1001. (https://doi.org/10.1111/j.1365-2826.2011.02141.x)

3 Hillerer KM, Jacobs VR, Fischer T \& Aigner L. The maternal brain: an organ with peripartal plasticity. Neural Plasticity 20142014574159. (https://doi.org/10.1155/2014/574159)

4 Vanoye-Carlo A, Morales T, Ramos E, Mendoza-Rodríguez A \& Cerbón M. Neuroprotective effects of lactation against kainic acid treatment in the dorsal hippocampus of the rat. Hormones and Behavior 200853 112-123. (https://doi.org/10.1016/j. yhbeh.2007.09.004)

5 Cabrera V, Cantú D, Ramos E, Vanoye-Carlo A, Cerbón M $\&$ Morales T. Lactation is a natural model of hippocampus neuroprotection against excitotoxicity. Neuroscience Letters 2009461 136-139. (https://doi.org/10.1016/j.neulet.2009.06.017)

6 Cabrera V, Ramos E, González-Arenas A, Cerbón M, CamachoArroyo I \& Morales T. Lactation reduces glial activation induced by excitotoxicity in the rat hippocampus. Journal of Neuroendocrinology 201325 519-527. (https://doi.org/10.1111/jne.12028)

7 Djebaili M, Lerner-Natoli M, Pascale M, Baille V, Bockaert J \& Rondouin G. Molecular events involved in neuronal death induced in the mouse hippocampus by in-vivo injection of kainic acid. Molecular Brain Research 200193 190-198. (https://doi.org/10.1016/ S0169-328X(01)00197-8)

8 Wisden W \& Seeburg P. A complex mosaic of high-affinity kainate receptors in rat brain. Journal of Neuroscience 199313 3582-3598.

9 Pollard H, Charriaut-Marlangue C, Cantagrel S, Represa A, Robain O, Moreau J \& Ben-Ari Y. Kainate-induced apoptotic cell death in hippocampal neurons. Neuroscience 199463 7-18. (https://doi. org/10.1016/0306-4522(94)90003-5)

10 Neville MC, McFadden TB \& Forsyth I. Hormonal regulation of mammary differentiation and milk secretion. Journal of Mammary Gland Biology and Neoplasia 20027 49-66. (https://doi. org/10.1023/A:1015770423167)

11 Harvey S. Extrapituitary growth hormone. Endocrine 201038 335-359. (https://doi.org/10.1007/s12020-010-9403-8)

12 Trott JF, Vonderhaar BK \& Hovey RC. Historical perspectives of prolactin and growth hormone as mammogens, lactogens and galactagogues-Agog for the future! Journal of Mammary Gland Biology and Neoplasia 200813 3-11. (https://doi.org/10.1007/s10911-0089064-x)

13 Arámburo C, Alba-Betancourt C, Luna M \& Harvey S. Expression and function of growth hormone in the nervous system: a brief review. General and Comparative Endocrinology 2014203 35-42. (https://doi. org/10.1016/j.ygcen.2014.04.035)

14 Weigent DA. High molecular weight isoforms of growth hormone in cells of the immune system. Cellular Immunology 2011271 44-52. (https://doi.org/10.1016/j.cellimm.2011.06.001)

15 Luna M, Martínez-Moreno CG, Ahumada-Solórzano MS, Harvey S, Carranza M \& Arámburo C. Extrapituitary growth hormone in the chicken reproductive system. General and Comparative Endocrinology 2014203 60-68. (https://doi.org/10.1016/j.ygcen.2014.02.021)

16 Addison ML \& Rissman EF. Sexual dimorphism of growth hormone in the hypothalamus: regulation by estradiol. Endocrinology 2012153 1898-1907. (https://doi.org/10.1210/en.2011-1982)

17 Tang H, Zhang Y, Yu X, Song J, Xu C \& Wan Y. Changes in growth hormone $(\mathrm{GH})$, GH receptor, and GH signal transduction in hippocampus of congenital hypothyroid rats. Journal of Neuroscience Research 201189 248-255. (https://doi.org/10.1002/jnr.22540)
18 Lobie PE, García-Aragón J, Lincoln DT, Barnard R, Wilcox JN \& Waters MJ. Localization and ontogeny of growth hormone receptor gene expression in the central nervous system. Brain Research: Developmental Brain Research 199374 225-233. (https://doi. org/10.1016/0165-3806(93)90008-X)

19 Aberg ND, Brywe KG \& Isgaard J. Aspects of growth hormone and insulin-like growth factor-I related to neuroprotection, regeneration, and functional plasticity in the adult brain. Scientific World Journal 20066 53-80. (https://doi.org/10.1100/tsw.2006.22)

20 Aberg D. Role of the growth hormone/insulin-like growth factor 1 axis in neurogenesis. Endocrine Development 201017 63-76. (https:// doi.org/10.1159/000262529)

21 Isgaard J, Aberg D \& Nilsson M. Protective and regenerative effects of the GH/IGF-I axis on the brain. Minerva Endocrinologica 200732 103-113.

22 Arce VM, Devesa P \& Devesa J. Role of growth hormone (GH) in the treatment on neural diseases: from neuroprotection to neural repair. Neuroscience Research 201376 179-186. (https://doi.org/10.1016/j. neures.2013.03.014)

23 Devesa J, Reimunde P, Devesa P, Barberá M \& Arce V. Growth hormone (GH) and brain trauma. Hormones and Behavior 201363 331-344. (https://doi.org/10.1016/j.yhbeh.2012.02.022)

24 Harvey S, Lavelin I \& Pines M. Growth hormone (GH) action in the brain: neural expression of a GH-response gene. Journal of Molecular Neuroscience 200218 89-95. (https://doi.org/10.1385/JMN:18:1-2:89)

25 Schneider HJ, Pagotto U \& Stalla GK. Central effects of the somatotropic system. European Journal of Endocrinology 2003149 377-392. (https://doi.org/10.1530/eje.0.1490377)

26 Scheepens A, Sirimanne ES, Breier BH, Clark RG, Gluckman PD \& Williams CE. Growth hormone as a neuronal rescue factor during recovery from CNS injury. Neuroscience 2001 104 677-687. (https:// doi.org/10.1016/S0306-4522(01)00109-9)

27 Torres-Aleman I. Toward a comprehensive neurobiology of IGFI. Developmental Neurobiology 201070 384-396. (https://doi. org/10.1002/dneu.20778)

28 Puche JE \& Castilla-Cortázar I. Human conditions of insulin-like growth factor-I (IGF-I) deficiency. Journal of Translational Medicine 201210 224. (https://doi.org/10.1186/1479-5876-10-224)

29 Wang Q, Yu S, Simonyi A, Sun GY \& Sun AY. Kainic acid-mediated excitotoxicity as a model for neurodegeneration. Molecular Neurobiology 200531 3-16. (https://doi.org/10.1385/MN:31:1-3:003)

30 Arellanes-Licea EC, Báez-Ruiz A, Carranza ME, Arámburo C, Luna M \& Díaz-Muñoz M. Daily patterns and adaptation of the ghrelin, growth hormone and insulin-like growth factor-1 system under daytime food synchronisation in rats. Journal of Neuroendocrinology 201426 282-295 (https://doi.org/10.1111/jne.12145)

31 Xing W, Deng M,Zhang J, Huang H,Dirsch O \& Dahmen U. Quantitative evaluation and selection of reference genes in a rat model of extended liver resection. Journal of Biomolecular Techniques 200920 109-115.

32 Hvid H, Ekstrøm CT, Vienberg S, Oleksiewicz MB \& Klopfleisch R. Identification of stable and oestrus cycle-independent housekeeping genes in the rat mammary gland and other tissues. Veterinary Journal 2011190 103-108. (https://doi.org/10.1016/j.tvjl.2010.09.002)

33 Livak KJ \& Schmittgen TD. Analysis of relative gene expression data using real-time quantitative PCR and the 2(-Delta Delta C(T)) method. Methods 200125 402-428. (https://doi.org/10.1006/ meth.2001.1262)

34 Vandesompele J, De Preter K, Pattyn F, Poppe B, Van Roy N, De Paepe A \& Speleman F. Accurate normalization of real-time quantitative RT-PCR data by geometric averaging of multiple internal control genes. Genome Biology 20023 research0034.1research0034.11.

35 Morales T, Lorenson M, Walker AM \& Ramos E. Both prolactin (PRL) and a molecular mimic of phosphorylated PRL, S179D-PRL, http://www.endocrineconnections.org https://doi.org/10.1530/EC-17-0380
(๔) 2018 The authors Published by Bioscientifica Ltd

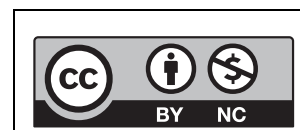

This work is licensed under a Creative Commons Attribution-NonCommercial 4.0 International License. 
protect the hippocampus of female rats against excitotoxicity. Neuroscience 2014258 211-217. (https://doi.org/10.1016/j. neuroscience.2013.11.015)

36 Tejadilla D, Cerbón M \& Morales T. Prolactin reduces the damaging effects of excitotoxicity in the dorsal hippocampus of the female rat independently of ovarian hormones. Neuroscience 2010169 1178-1185. (https://doi.org/10.1016/j.neuroscience.2010.05.074)

37 Wehrenberg WB \& Gaillard RC. Neuroendocrine mechanisms regulating growth hormone and prolactin secretion during lactation. Endocrinology 1989124 464-467. (https://doi.org/10.1210/endo-124-1-464)

38 Escalada J, Sánchez-Franco F, Velasco B \& Cacicedo L. Regulation of growth hormone $(\mathrm{GH})$ gene expression and secretion during pregnancy and lactation in the rat: role of insulin-like growth factor-I, somatostatin, and GH-releasing hormone. Endocrinology 1997138 3435-3443. (https://doi.org/10.1210/endo.138.8.5342)

39 Travers MT, Madon RJ, Vallance AJ \& Barber MC. Circulating concentrations and hepatic expression of IGF-1 during pregnancy and lactation in the mouse. Biochemical Society Transactions 199018 1268

40 Pan W, Yu Y, Cain CM, Nyberg F, Couraud PO \& Kastin AJ. Permeation of growth hormone across the blood-brain barrier. Endocrinology 2005146 4898-4904. (https://doi.org/10.1210/ en.2005-0587)

41 Chen ZL, Indyk JA, Bugge TH, Kombrinck KW, Degen JL \& Strickland S. Neuronal death and blood-brain barrier breakdown after excitotoxic injury are independent processes. Journal of Neuroscience 199919 9813-9820.

42 Barber MC, Travers MT, Finley E, Flint DJ \& Vernon RG. Growthhormone-prolactin interactions in the regulation of mammary and adipose-tissue acetyl-CoA carboxylase activity and gene expression in lactating rats. Biochemical Journal 1992285 469-475. (https://doi. org/10.1042/bj2850469)

43 Beauloye V, Willems B, de Coninck V, Frank SJ, Edery M \& Thissen JP. Impairment of liver GH receptor signaling by fasting. Endocrinology 2002143 792-800. (https://doi.org/10.1210/endo.143.3.8692)

44 Aguila MC \& McCann SM. Growth hormone increases somatostatin release and messenger ribonucleic acid levels in the rat hypothalamus. Brain Research 1993623 89-94. (https://doi. org/10.1016/0006-8993(93)90014-E)

45 Herrington J \& Carter-Su C. Signaling pathways activated by the growth hormone receptor. Trends in Endocrinology and Metabolism 200112 252-257. (https://doi.org/10.1016/S1043-2760(01)00423-4)

46 Quinnies KM, Bonthuis PJ, Harris EP, Shetty SR \& Rissman EF. Neural growth hormone: regional regulation by estradiol and/or sex chromosome complement in male and female mice. Biology of Sex Differences 20156 8. (https://doi.org/10.1186/s13293-015-0026-x)
47 Sakaguchi K, Tanaka M, Ohkubo T, Yoshizato H, Hanai Y, Fujikawa T, Kaneko H \& Nakashima K. Tissue-specific regulation of growth hormone receptor and growth hormone binding protein gene expression during pregnancy and lactation in the rat. Endocrine Journal 199845 S105-S107. (https://doi.org/10.1507/endocrj.45. Suppl_S105)

48 Devesa P, Reimunde P, Gallego R, Devesa J \& Arce VM. Growth hormone $(\mathrm{GH})$ treatment may cooperate with locally-produced $\mathrm{GH}$ in increasing the proliferative response of hippocampal progenitors to kainate-induced injury. Brain Injury 201125 503-510. (https://doi. org/10.3109/02699052.2011.559611)

49 Chia DJ. Minireview: mechanisms of growth hormone-mediated gene regulation. Molecular Endocrinology 201428 1012-1025. (https:// doi.org/10.1210/me.2014-1099)

50 Mathews LS, Norstedt G \& Palmiter RD. Regulation of insulin-like growth factor I gene expression by growth hormone. PNAS $1986 \mathbf{8 3}$ 9343-9347. (https://doi.org/10.1073/pnas.83.24.9343)

51 Frago LM, Pañeda C, Dickson SL, Hewson AK, Argente J \& Chowen JA. Growth hormone (GH) and GH-releasing peptide-6 increase brain insulin-like growth factor-I expression and activate intracellular signaling pathways involved in neuroprotection. Endocrinology 2002143 4113-4122. (https://doi.org/10.1210/ en.2002-220261)

52 Miltiadous P, Stamatakis A \& Stylianopoulou F. Neuroprotective effects of IGF-I following kainic acid-induced hippocampal degeneration in the rat. Cell Molecular Neurobiology 201030 347-360. (https://doi.org/10.1007/s10571-009-9457-4)

53 Alba-Betancourt C, Luna-Acosta JL, Ramírez-Martínez CE, AvilaGonzález D, Granados-Ávalos E, Carranza M, Martínez-Coria H, Arámburo C \& Luna M. Neuro-protective effects of growth hormone (GH) after hypoxia-ischemia injury in embryonic chicken cerebellum. General and Comparative Endocrinology 2013183 17-31. (https://doi.org/10.1016/j.ygcen.2012.12.004)

54 Martínez-Moreno CG, Ávila-Mendoza J, Wu Y, Arellanes-Licea ED Louie M, Luna M, Arámburo C \& Harvey S. Neuroprotection by GH against excitotoxic-induced cell death in retinal ganglion cells. General and Comparative Endocrinology 2016234 68-80. (doi:10.1016/j.ygcen.2016.03.023)

55 vila-Mendoza J, Mora J, Carranza M, Luna M \& Arámburo C. Growth hormone reverses excitotoxic damage induced by kainic acid in the green iguana neuroretina. General and Comparative Endocrinology 2016 234 57-67. (https://doi.org/10.1016/j.ygcen.2016.04.004)

56 Pathipati P, Gorba T, Scheepens A, Goffin V, Sun Y \& Fraser M. Growth hormone and prolactin regulate human neural stem cell regenerative activity. Neuroscience 2011190 409-427. (https://doi org/10.1016/j.neuroscience.2011.05.029)

Received in final form 25 December 2017

Accepted 10 January 2018

Accepted Preprint published online 10 January 2018 http://www.endocrineconnections.org https://doi.org/10.1530/EC-17-0380
(C) 2018 The authors Published by Bioscientifica Ltd

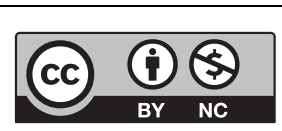

This work is licensed under a Creative Commons Attribution-NonCommercial 4.0 International License. 